\title{
Virtual Water Trade as a creative water-saving technique
}

\section{Hadeer Khaled Mohamed El-Sayed El-Batanouny}

Assistant Lecturer

Economics and Foreign Trade Department - Faculty of

Commerce and Business Administration - Helwan University

\section{Abstract:}

Understanding the idea and strategy of virtual water trade is critical for formulating informed policies to increase water usage efficiency at various levels. The implementation of the concept of virtual water as a creative water-saving technique in Egypt, however, is still in need of comprehensive testing, research, and feasibility evaluation. Egypt also requires extensive investigations, surveys, and feasibility evaluations. At present, as a percentage of water supplies, Egypt's net virtual water import has risen to 23.55 percent. The primary concern here is to apply virtual water as a strategy that meets the interests and goals set out in Egypt's National Water Management Plan. The key concern of this paper is investigating the general use of virtual water as a water-saving technique in Egypt. It outlines the water scarcity problem and its indicators, supply and demand for water resources in Egypt, and water scarcity forces in Egypt. Going to virtual water in economic ideas history, the definitions of virtual 
water and water footprint, then virtual water as an analytical instrument and a political strategy. Finally, water saving from virtual water trade and its advantages and disadvantages in Egypt. In order to follow the introduction of the virtual water definition in the national water management policy of Egypt, A clear vision and understanding of its advantages and disadvantages according to the conditions of Egypt is required. Further analysis and a thorough understanding of the impacts and experiences on the local social, economic, environmental, cultural, natural and political situation is needed for this new definition as a policy choice in Egypt.

Keywords: water scarcity, supply and demand for water resources, virtual Water, virtual water trade, Water saving from virtual water trade, advantages and disadvantages of virtual water trade.

\section{Introduction:}

Water, an essential commodity for the life of all human beings and the growth and well-being of human societies, is finitely accessible in global, regional, and national-territorial theatres. The need for it is not as finite at individual and national levels, but rather is increasingly motivated by improved technical supplies and uses; by enhanced profits. That has enhanced better living standards and net population growth at the national level. Coupled with management challenges at individual, national and 
regional levels, when faced with a lack of cooperation at national, regional, and international levels, water challenges have become severe and insurmountable (Haddadin, 2003).

One of the critical measures of the water deficit rate of water scarcity is the amount of its food imports is determined by countries. Food imports are such a strong predictor of a water deficit that an economist would refer to as the water's dominant consumption is the water needed to grow food. Whether viewed from the viewpoint of the individual citizen or the national economy, usage is prevalent. Water used in the agricultural sector reaches ten times the combined manufacturing and urban industries (Allan, 1998).

Restricted water supplies are the principal challenge facing Egyptian national growth. The central factor determining the form, size, and location of any economic activity is water. Egypt is a very arid country where, along the northern coast, the average annual rainfall barely reaches $200 \mathrm{~mm}$. The rain decreases very quickly from the coastline to the inland areas and becomes almost zero south of Cairo. In the winter, this meager precipitation occurs in sporadic showers and cannot be relied on for extensive agricultural production.

The secure availability of irrigation water is thus a critical condition for the growth of agriculture. In Egypt, the agriculture sector uses about 85 percent of the water resources. Therefore, 
before jumping to conclusions about the suitability of virtual water trade as a policy alternative, it is essential to investigate these issues.

\section{1- Water Scarcity Problem:}

Although water constitutes about $75 \%$ of our planet and gives the impression that water is considered an abundant resource on earth, this indicator is a misleading one. The illusion of abundant water would soon vanish as soon as we knew that $97 \%$ of such available water is salty seawater, another $2 \%$ is locked on ice caps, and only $1 \%$ of the open water on earth holds the hope of more than 6 billion people for meeting their water demand derived from the need of the food that must be grown and the industry that must be run. Also, the decent life with its drinking water requirements and proper sanitation, and other domestic uses (UNEP, 2003).

Accordingly, the term "water resources" describes only the Freshwater that could be used to meet the different human benefits while excluding seas and oceans' water from being included in this term.

Given that the amount of water resources available is almost fixed and chased by a growing demand derived from different forces, mainly the pressure of increasing population, moving 
away from the era of plenty water to the period of limited water resources (wWw.oced.org).

\section{2- Water Scarcity Indicators:}

In this part, there are three different indicators for determining the cause of the water resources limitation. Some of these indicators could be presented as follows:

\section{First: The Quantitative Indicator:}

According to this indicator, which is also called the Falkenmark indicator, physical water scarcity would occur when the available water resources are insufficient to meet all demands. The case of water resources limitation here could be described as follows (Amarasinghe Upali et al., 1999).

a- Occasional or local water problem: when the annual freshwater supplies available per person are slightly higher than $1700 \mathrm{~m}^{3}$. The terminology here stems from the idea that water scarcity is scarce above this yearly per capita water supply level. If it exists, it is only a problem within a few localities.

b- Water stress: when the yearly freshwater supplies available per person range between $1000 \mathrm{~m}^{3}$ and $1700 \mathrm{~m}^{3}$.

C- Water scarcity: when the fresh yearly water supplies available per person are less than $1000 \mathrm{~m}^{3}$ based on the estimate that $1000 \mathrm{~m}^{3}$ is the water poverty limit. In this case, the lack of 
water begins to hamper the health and the well-being of humans and is a severe restraint on food production and economic development.

d- Absolute water scarcity: when the annual freshwater supplies available per person fall below $500 \mathrm{~m}^{3}$. Under this condition, the shortage is a severe constraint to human life.

In this regard, as the amount of Freshwater is almost fixed, the per capita available waterfalls as the population rise, pushing more and more countries into water stress and water scarcity over time.

\section{Second: The Qualitative Indicator:}

This indicator focuses on the quality of water. According to this indicator, water scarcity is determined by the pollution of the available water resources. The case exists within which all or part of the open water resources are inapplicable or inappropriate for meeting the development uses in the agricultural and industrial areas. The livelihoods sector, as a result of being polluted, is a qualitative indicator of water scarcity. The justification here is that, even if water exists with plenty of quantity but being corrupted, the only outcome is that such water can't be used to meet the development uses of Water (Tayie Mohamed, 2005). 


\section{Third: The Economic Indicator:}

According to this indicator, economic water scarcity would occur when adequate water resources exist in nature. Still, it is because of the lack of financial, human, or institutional capacity that is likely to be insufficient to create the needed investments required to make such water resources accessible for different development purposes. Symptoms of economic water shortage include inadequate construction of infrastructures so that people have trouble getting enough water for agriculture and domestic purposes (Molden D. et al., 2007).

The lack of finance, lack of human capacity, and poor management constrain the accessibility to the water resources that are already plenty in nature, restrict the ability to keep up with the growing water demand, and consequently give rise to water scarcity.

In this regard, 9 out of 10 Nile basin countries are ranked among the world's poorest countries. Accordingly, even though the Nile basin is endowed with natural resources, such countries face economic water scarcity. Economic poverty bends their ability to establish the essential infrastructure needed to make water access possible for different purposes. However, such water resources are plentiful ( Tayie Mohamed, 2005) ( Mohamed Yasir et al., 2008). 
According to the above indicators, the idea of water scarcity in Egypt could be viewed from either the quantitative and qualitative indicators.

\section{3- Supply and Demand for Water Resources in Egypt:}

Country Water resources are only the conventional water sources' total available resources and non-conventional in a certain period. Moreover, conventional water resources consist of surface sources, including rain, rivers, valleys, rain, flooding, groundwater, renewable, and non-renewable water. The nonconventional water resources include desalination, saline groundwater, and wastewater treatment and reuse of agricultural drainage water. Population growth and the attendant growth in various industrial and commercial activities, and the limited agricultural area are the most critical challenges facing most countries in the world these days. In Egypt, increased demand for food and water consumed all water resources available (AbdelShafy \& Aly, 2002).

Egypt is a very arid country, with only 1.18 percent of annual water resources comes from rainfall and 9.03 percent from underground sources, leaving the Nile River as the reliable primary source of Water in Egypt. Egypt receives a constant amount of water, 55,500 billion cubic meters, through the Nile River annually. This amount of water accounts for $72.64 \%$ of the Egyptian annual water resources (CAPMAS, 2017). 
On the other hand, the population grew in Egypt from about 38 million in 1977 to about 92 million people in 2013. Nowadays, the population in January 2021 is $101,450,762$. Due to population growth, water demand has increased to exceed its constant annual supply. Egypt has begun to experience the problem of a shortage of per capita freshwater. This problem can turn into a severe crisis. The country can't meet the food requirements and provide food security for all the population, which will decrease the average per capita availability of Water in Egypt for the water poverty line, estimated at 1,000 cubic meters per year (FAO, 2017a).

In Egypt, per capita water resources were about 2189 cubic meters in 1966 and continued to decline, until it became in 1986, about 1110 cubic meters, then reached around 771 cubic meters in 2005, and this decline will continue as long as the rate of increase in the population remained as it is with no increase in available water resources. Besides, it is expected that per capita will be less than 500 cubic meters in 2025 compared to 550 cubic meters in 2018, and which will cause a severe crisis for the Egyptian economy if the country did not move toward comprehensive national plans to solve the problem of water and food security (CAPMAS, 2017) (FAO, 2017a).

This part starts by analyzing the supply side of the water resources by giving an overview of the different sources of water supply in Egypt (conventional and non-conventional sources) and 
their determinants, then the demand side analysis through providing an overview of the water demand in different economic productive sectors and their elasticity.

\section{4- Water Supply Sources:}

There are different ways of classifying the available water resources in a particular district. The clearest and commonly used one is to organize the available water resources according to the source from which such resources became available. In this regard, the Freshwater could be sourced from either conventional or non-conventional sources as would be clarified as follows, taking into consideration that each of the following water sources has its limitations used. Whether those constraints relate to quantity, quality, time, or cost of exploitation (Bates et al., 2005) (ENCID, 1996).

\subsection{Conventional Water Sources:}

Conventional water sources could take the form of either "surface sources" or "groundwater." Surface sources are those open to the atmosphere and resulted from either the water movement under the earth's surface, such as lakes and river streams, or the rainfalls that pass over the earth's surface. Groundwater exists below the earth's crust in depth not more than 2500 feet below the crust to be considered usable Freshwater (El-Sadek, A., 2008). 
In this regard, Egypt's conventional water sources are limited to the Nile River, rainfall and flash floods, the west desert groundwater, and the Sinai. A brief overview of each of those sources could be presented as follows:

\section{1- $\quad$ Surface water (Nile River):}

It is considered the primary source of fresh water in Egypt, as it provides more than 95 percent of the country's various water needs. The 1959 treaty between Egypt and Sudan calculated the Nile river's total annual yield at Aswan to be 84 billion cubic meters (BCM). According to this treaty, this quantity of water is to be distributed between both countries. Egypt's annual share is determined as 55.5 BCM, and Sudan's yearly percentage is defined as $18.5 \mathrm{BCM}$. In comparison, the remaining $10 \mathrm{BCM}$ are considered as various water losses. In 1970, and its large storage capacity in Lake Nasser, Egypt has obtained a steady annual revenue from the Nile River's Water. The Nile water represented about $86.7 \%$ of Egypt's total water resources in 2006 and is expected to decrease its contribution of the complete available water resources for use in Egypt to 72.64\% in 2017 (CAPMAS, 2017) (Hassan Mohamed et al., 2005) (MWRI, 2010).

The High Aswan Dam (HAD) presently ensures Egypt sustains its annual quota of water throughout the year in the lake Nasr's storage. The release of water is adjusted throughout the year to provide water for the different sectors (MWRI, 2002) (MWRI, 2010). 


\section{2- Rainfall and Flash Floods:}

Egypt is a desert country, and rain is a limited source of water. In Egypt, rainfall rates range from 20 to 150 millimeters per year over the North West Coast, sometimes up to 500 millimeters per year on the Red Sea coasts of Halaib, Shalatin, and Abu Samad in the southeast. The rate of evaporation from the earth's surface is estimated at around $30 \mathrm{~mm}$ per year. Therefore, Egypt is under arid areas, and temporal and spatial irregularities characterize the rainfall (MWRI, 2010).

Although rains in Egypt, which occurs only in winter and in the form of a scattered shower, can't be considered a dependable or reliable source of water, due to its spatial and temporal variability, some seasonal rain-fed agriculture is practiced in the northern coast to the west of Alexandria and in Sinai using this small amount of water.

\section{3- Underground Water:}

Groundwater is a freshwater resource in Egypt and is essential as the sole and critical resource in Egypt's deserts. Egypt's dependence on groundwater increased in 2017 to represent about $11.8 \%$ of the total available water resources. Groundwater in the Nubian Sandstone is in Western Sahara is an essential source of groundwater where estimated groundwater is entering the 
country Nubian aquifer fed by about 1 billion cubic meters per year (Hassan Mohamed et al., 2005).

\subsection{Non-conventional water resources:}

Non-conventional water sources include desalination of seawater and brackish groundwater, Nile valley and Delta groundwater, agricultural drainage water reuse, and municipal wastewater treatment reuse. A summary of each of these sources could be presented as follows,

\section{1-Seawater desalination:}

Desalination is simply the process of removing salts and minerals from water to be processed into Freshwater suitable for use or irrigation by humans. This process could be implemented on seawater and brackish groundwater. Although desalination requires a large amount of energy as well as specialized and expensive infrastructure and accordingly became very costly compared to the use of Freshwater from rivers or groundwater, it might be crucial to use such source in the future if the growth of the water demand exceeds all other available sources of water. In turn, this would depend on creating and developing cost-effective ways and technologies for the desalination process, especially for the low economies (MWRI, 2010).

In this respect, it was found that seawater's desalination has not yet been given a high priority in Egypt as a water source. This is 
because of the high cost of treating seawater (Hassan Mohamed et al., 2005).

However, this method can often be used to supply domestic water, particularly in remote areas where construction costs are high despite this high cost. The pipelines required to transfer the Nile water is relatively high. This is practiced in the red sea coastal areas to supply tourism villages with adequate domestic water. In such a case, water's economic value is high enough to cover the desalination costs (MWRI, 2010).

The future use of such a source of water for other purposes, namely the agricultural and industrial sectors, will largely depend on the rate of improvement in the technologies used in this area ( i.e., the use of desalinated water in Egypt is currently restricted to domestic services because of the high price of this method). On the other hand, it is possible to desalinate the brackish groundwater with a salinity of about $10,000 \mathrm{ppm}$ (parts per million) at a fair cost and thus have a desalinated water capacity in agriculture (MWRI, 2010)

\section{2-Groundwater in the Nile valley and Delta:}

Unlike the groundwater in the western desert and Sinai recharged by rainfall and flash floods, The aquifer of groundwater that underlies the Nile Valley and Delta is not formed by natural topography. Still, it is created and restored by the seepage losses 
from the Nile, the irrigation canals and drains, and deep percolation of water from irrigated lands. Thus, this water source is considered a non-conventional source of Water (MWRI, 2010).

Such a source of water can't be dealt with as an independent source of water. Its use is perceived as nothing but a recycling of the previously used Nile freshwater source as a mean for maximizing the utilization of the available water resources and enhancing the efficiency of the overall water distribution system (i.e., if the water distribution system and infrastructure were appropriately used and is subject to periodical maintenance, such seepage would have decreased if not being almost eliminated) (ICID, 2004) (MWRI, 2010).

Although the total storage of the Nile aquifer is estimated at 500 $\mathrm{BCM}$, the maximum renewable amount (the safe aquifer yield) is just around 7.5 BCM per year, where the abstraction of groundwater in the valley and Delta regions is estimated to be about $7 \mathrm{BCM}$ in 2009 which is still below the aquifer potential safe yield (ENCID, 1996) (ICID, 2005).

\section{3-Reuse of agricultural drainage water:}

Agricultural drainage water is simply the amount of water that returns to drains from irrigated lands. Such drainage flow comes from different sources, at which none of them is independent of the Nile River. Among these sources is the surface runoff from 
irrigated fields resulting from excess water above the irrigated crop's water requirement.

In this connection, the amount of water returned to the drains from irrigated lands is relatively high, ranging from 25 to $30 \%$. Such water drainage is still considered to be freshwater with good quality. Actually, the southern part of Egypt's agricultural drainage returns to the Nile River and is mixed with its fresh water and used for different purposes downstream (MWRI,2010).

The agricultural sector is the biggest consumer of fresh water in Egypt, using about $86 \%$ of the available supplies. All of the agricultural drainage water in Upper Egypt, south of Cairo, is back to the Nile River and irrigation canals. All this water is transported and reused by the large-scale agricultural drainage network managed and planned by the Ministry of Water Resources and Irrigation.

The reuse of agricultural wastewater has been widespread over the past decades, with water being pumped from the central banks into the main channels. More than 5.5 billion cubic meters per year of wastewater are being reused after mixing with fresh water and an informal amount used by farmers in many locations, without coordination or regulation with the Ministry of Water Resources Irrigation (Abdel Wahaab, R., \& Omar, M., 2011) 
The use of agricultural wastewater increased to 9.6 billion cubic meters per year by 2017. The reuse of wastewater in the Nile Delta region began in the early 1930s. Laws and declarations, including guidelines for mixing agricultural wastewater with Freshwater, sewage and industrial systems, wastewater reuse, cropping patterns, health protection measures, specifications, and standards. However, the main problem lies in weak regulatory compliance and enforcement of these laws and declarations (CAPMAS, 2017).

\section{4-Recycling of treated municipal wastewater:}

Wastewater is the water that has been negatively affected by human actions by some way, such as the liquid wastes discharged by domestic and industrial uses. Based on that, the term "municipal" wastewater would refer to the result of mixing wastewaters disposed of from different sources.

In this respect, the increasing demand for domestic water (due to population growth and improvement in living standards) and the growing use of water in the industrial sector ( due to its expansion) would increase the total amount of wastewater available. Such wastewater could be treated in a certain way that would allow it to be reused in the agricultural sector, with or without being mixed with the Freshwater, as a means for augmenting irrigation water for this high water-consuming sector ( Hassan Mohamed et al., 2005). 
Accordingly, this water source can't be treated as an independent source of water as it represents the reuse of the previously utilized Nile fresh water. It can be dealt with to maximize the available water resources (ICID, 2005).

Going in more depth, it is worth mentioning that, although the amount of water resources in Egypt is currently perceived as being almost fixed, it could be increased or decreased depending on a set of factors. Among these factors or determinants of water supply are the political factor, climate conditions, and variability.

Concerning the political factor, it is related mainly to the Nile River. This is because the Nile River, which is considered the primary water source in Egypt, originates from outside the Egyptian international borders. The Nile River has stretched over ten countries, known as the Nile basin countries, including Egypt, Burundi, the Democratic Republic of the Congo, Kenya, Ethiopia, Rwanda, Sudan, Tanzania, Eritrea, and Uganda. The Nile starts its journey from the equatorial region in the south, moving towards the Mediterranean sea in the north of Egypt ( Wu Xun et al., 2005).

The primary source of Water in Egypt originates from outside its international borders. It emphasized the importance of enhancing and dominating the Egyptian political relationships with the sourcing countries, especially Ethiopia, which provides Egypt with $85 \%$ of its annual quota of the Nile River. Such 
enhancement and domination of the political relations with the sourcing countries are essential not only as a mean of securing the Egyptian share of the Nile River and its flow to Egypt but also as a helpful tool that could facilitate any negotiations aiming at increasing Egypt's annual quota of the Nile River.

However, the possibilities of additional Nile water inflow to the lake Nasser in that respect are limited because the population in the upstream countries and their derived demand on the water are booming and the potential irrigation projects there (Mohamed Yasir et al., 2008).

Moreover, Egypt's neighbor Nile basin countries' internal political stability is another dimension for the political factor that has an essential impact on Egypt's water resources. Such a fact is embodied in the problem of the Jonglei Canal project. (Suliman Mohamed, 1998)

The Jonglei Canal project was considered to be one of the essential integration projects between Egypt and Sudan in the sense that it was designed to make full use of the Nile River by conserving about 4.7 $\mathrm{BCM}$ of Water that was lost annually through evaporation and distribute such annual conserved water equally between the two countries. The actual construction of the Canal began in 1978. Still, it was forcibly suspended in 1984, after completing the excavation of $250 \mathrm{~km}$ out of the proposed $360 \mathrm{~km}$, due to the breakout of Sudan's political instability and 
the following series of attacks on Sudan's construction site People's liberation army.

Accordingly, Egypt was prevented from gaining about 2 BCM annually due to such political instability in Sudan that kept the Jonglei Canal project halted since 1984.

On the other side, if climate variability and global warming are considered, there will be severe potential impacts on water resources. The link between climate changes and water resources is embodied in the natural hydrological water cycle. Although the temperature rise increases water evaporation rate, especially for the free surface water as the Nile River, affecting the available supply of water resources negatively, such evaporated water then condensates on-air, forming clouds precipitate causing rainfall affecting the public water supply positively (Seckler D. et al., 1998).

In this regard and in assessing the net potential impact of climate change on Egypt's available water resources, various studies argued that climate change is expected to negatively affect Egypt's water resources. This argument is based on the idea that the rainfall rate is not likely to change significantly in the area starting from Sudan until the HAD due to its topography. The potential evaporation rate is increasing dramatically exceeds the percentage of the rainfall. 
Accordingly, the global warming phenomena are expected to reduce Nile water flow to Egypt to the extent that it might reach around a 25\% reduction in the Nile river flow over the next 20 to 40 years (Sabry, R. et al., 2007).

\section{5- Water Demand Sources:}

The central pillar of life, the demand for water resources, would be derived from all the sectors prevailing in any economy for both productive and consumptive uses. In this regard, the evaluation of the derived demand for water in the irrigation and industrial sectors in order to represent the efficient use of water is devoted to this portion. The water resource is used as an input. In contrast, the municipal demand for water would be assessed as water demand for navigation would also be evaluated (Ahmed M.,2002).

\section{1-Irrigation Water Demand:}

Egypt's agricultural sector is the dominant water user, capturing about $60.731 \mathrm{BCM}$ annually, equivalent to $85 \%$ of the overall water sources available per year. However, this quantity of water diverted for the agricultural sector doesn't necessarily reflect the crops' irrigation requirements, estimated to be only $41.441 \mathrm{BCM}$ annually. Besides, efforts enabled Egypt to increase irrigated land from 6 million feddans in 1980 to more than 8 million feddans in 
2010. The state policy requires continuous horizontal agricultural expansion to track the population's steady increase (ICID, 2004).

The irrigation water withdrawal typically exceeds the crops' irrigation requirements because of the water lost in the water distribution from its source to the crops. Such unused water referred to as distribution and application losses are positively affected by the evaporation rate from the open water surface, which is determined by the climatic conditions (temperature, humidity, wind speed, and solar radiation), the irrigation method used (knowing that $90 \%$ of the old agricultural lands in Egypt rely on the surface irrigation). The rate of infection of the canals and drains with aquatic weeds (MWRI, 2002).

On the other hand, the crops' irrigation requirement is also determined partially by the climatic conditions (within which the irrigation requirements of the crop would increase with the increase in the temperature and the wind speed, and the solar radiation period, and the decrease in humidity) in addition to the kind of the crop and its growth stage (at which rice and sugarcane are considered to be the highest water consuming crops) as well as the type of the soil (Sharma, B., 2006).

\section{2- Industrial Water Demand:}

The needs of the industrial sector are an integral part of Egypt's water policy. The current uses of industrial parts are about 1.1 
billion cubic meters per year of water. Following the method used to calculate the water needs for drinking purposes, the industry's water needs can be expected, assuming the average growth rate of $4 \%$ per year. Taking that industrial water consumption patterns will vary over the coming period, new technologies in the industry and the industries' quality will reduce wastewater consumption (ICID, 2004).

\section{3- Municipal Water Demand:}

The municipal water demand includes the water required for major urban and rural villages for human activities like drinking, housekeeping, etc. It was estimated to be 9 BCM in 2009, which is equivalent to $12.59 \%$ of the overall water sources available annually $85 \%$ of this water comes from the Nile system while the remaining $15 \%$ is supplied from groundwater sources. However, only a small part of such diverted water is consumed while the remaining returns to the system through the sewage collection system or seepage to the groundwater. In this respect, the primary factor causing the inability to utilize the whole diverted amount of water is the efficiency of the delivery networks, as the average efficiency was as low as $50 \%$ and even less in some areas (ICID, 2004).

\section{4- Navigation Water Demand:}

Water use does not stop at the limit of agricultural, domestic, and 
industrial consumption but extends to several other benefits. The essential services are navigation, power generation, as well as environmental and recreational needs. Maintaining the salt balance in the northern agricultural land due to seawater interruption requires additional Nile water quantities. The disposal of agricultural, industrial, and household wastes in the waterways is water consumption in terms of the equivalent of deterioration of its quality.

The Nile river main channel and part of the irrigation network are used for navigation. This is considered a beautiful tourism tool in Egypt and a cheap and very safe transportation method (ICID, 2004).

The water demand specifically for navigation occurs only during the winter closure period (about three weeks in January and February). The water discharges to meet Many non-agricultural requirements are too small to have the minimum draft ships require. Such water then goes directly to the sea as Freshwater without being utilized (ICID, 2004) (ENCID, 1996).

Although the regular release of Freshwater to the sea is about $0.26 \mathrm{BCM}$ per year, due to leakage from barrage gates, this amount of Freshwater released directly to the sea was 6.517 BCM in 1999\2000 because of the high flood that occurred in that year and the two years before (ICID, 2005). 


\section{5- The driving Forces of Water Scarcity in Egypt:}

This part focuses on spotting the light on the main factors escalating water scarcity in Egypt, pushing it further in the future. Regarding such factors, some of them escalate the water scarcity conditions in the future, namely the impact of both population growth and improved life quality. In contrast, others contribute to the emergence of water shortages in the present.

There are other more critical factors in escalating the water issues in Egypt. They do not show direct linkages to the problem but significantly contribute to establishing water stress conditions. These driving forces are categorized into four different subgroups: social pressures, physical variables, economic forces, and political forces. A brief explanation for each could be shown as follows:

\section{1- Social Forces:}

The social pressures can be viewed at four levels. The different layers of the social forces that contribute to escalating the waterscarce conditions over time are impacts of poverty, inequity, cropping patterns and consumer behavior contribute to emerging of water shortages, which already exist. In contrast, the population growth and improved quality of life will occur later.

Knowing that Egypt has an annual population growth rate of $2 \%$, a population boost is being experienced in Egypt, raising the 
total population drastically over time. Such drastic population growth imposes pressure on the country's freshwater supplies for meeting the associated rapidly growing demand for domestic uses. Besides, additional derived pressure on the water supplies would be imposed by the agricultural sector for increasing its production to catch up with the increased need for food-derived by the increase in population. Accordingly, the available Freshwater per capita is subject to drastic decline over time due to this population boost (Abu Zeid, M., 2007).

Moreover, such an increased population is enjoying a better quality of life than in the past years, reflecting Egypt's accelerated economic growth over the last decades. This improvement in the quality of life could be indicated by the increased population ratio having access to piped water and sanitation facilities. Thus, as advancements in the quality of life are not without the expansion in water consumption for domestic uses, the enhancement in the quality of life and the continuous population growth keep pushing the demand for water up, imposing more and more pressure on the country's freshwater available (Wichelns, D., 2001).

Poverty and the current cropping pattern is also the main contributor to the existence of water scarcity. The majority of the rural population is low. Such poverty and low-income levels in rural areas restrict the farmers' ability to invest highly in 
agriculture, pushing them to invest in low-cost crops. Such lowcost crops are usually water-thirsty crops (as rice and sugarcane). This would, in turn, trigger an increase in water use.

Moreover, as the cropping pattern choice is affected by rural poverty and the profitability of crops, the rich farmers tend to expand their rice and sugarcane cultivation since such crops, especially rice, are a high-value crop and contribute highly to raising income. Thus, the profit-driven cropping pattern would also trigger an increase in water imposing more and more pressure on the available freshwater supplies (MWRI, 2002).

Adding more of the social factors escalating water scarcity, it has been found that the consumer's behavior, this derives from the level of education, accessibility, and availability of information and cultural patterns has a vital role in doing. The majority of the farmers resist using any new irrigation method, regardless of the innovations and new irrigation systems, and prefer to rely on the flood irrigation method they used to and are familiar with. Such behavior is more provoked by having almost free access to irrigation water that giver no signal to those farmers about the water scarcity problem in their country. Water is no more an inexhaustible resource (UNEP, 2002).

\section{2- Physical Variables:}

Water resources and land expansion represent the physical 
variables contributing to water shortage in Egypt.

Water Resources: it has been found that although the character of the water demand is growing up over time, the water supply is almost fixed, pushing the country to move towards intense shortages in water as time passes. The only hope for meeting such growing water derived demand is through irrigation improvements that can save vast bulk of water, expand drainage water reuse, and other non-conventional sources.

Land Expansion: it became an essential tool for the government to expand in land reclamation for agricultural purposes to provide food for the increasing population and meet the habitation requirements and the growing demand for jobs. However, the process of gaining new lands from the desert and reclaiming it using horizontal expansion would indeed require transferring water sources for such desert lands. Thus, such a land expansion method places an enormous strain on the water supply (UNEP, 2002).

\section{3- Economic Forces:}

As supplies fail to catch up with the growing demand, competition for water will increase to the benefit of domestic water users and at the expense of agriculture. The battle for water resources is to be intensified with water shortages or scarcity (as supplies fail to catch up with the increasing water demand); the agricultural sector is the 
most fragile subject to the hazard of losing its water supplies. This is because the agricultural sector is considered a relatively lowvalue water user (Abu Zeid, M., 2007).

\section{4- Political Forces:}

Water is a critical component of development in Egypt. However, limited water resources are not treated as a scarce commodity; on the contrary, it is heavily subsidized by the Egyptian government, which unintentionally promotes wasteful practices and hinders the emergence of rational use of resources. The subsidy issue involves many factors, and its removal would have widespread effects on society (Ahmed, 2002).

The removal of the irrigation water subsidy is not without its considerable impacts not only in the agricultural sector itself but also regarding the whole economy, pushing the government to keep pursuing such grants for the sake of political stability.

Such almost free water condition contributes to raising the water demand against the limited supply options. It sends a misleading signal about water resources' exhaustibility, thus triggering no incentive to save or rationalize its use. Wasteful practices and the growth of high water demanding crops are positively correlated with offering such high subsidy for the irrigation water (Abu Zeid, M., 2007). 


\section{6- Virtual Water in Economic Ideas History:}

For two centuries, a much more important idea than virtual water that of comparative advantage has been considered by Ricardo 1846 , even if it has been difficult to square the Heckscher-Ohlin model with actual trading patterns. Trade was shown to be a practical and mutually beneficial means of satisfying local strategic commodity needs. Ricardo drew attention to England and Portugal's useful mutual dependence concerning wine and cloth (Allan, T., 2003).

Virtual water is closely tied to the notion of comparative advantage from the theory of international trade (Allan, 1999; Wichelns, 2001). Essentially, countries can increase the overall value of citizens' goods and services by exporting products. The government has a relative or comparative production advantage while importing products, which have a comparative disadvantage.

For example, by importing water-intensive crops, countries in water-short regions can gain from trade while using their limited water supply for activities that generate higher incremental values. Professor Allan (1998) describes the role of international trade in virtual water movement from "comparatively advantageous regions; Where soil water surpluses in soil profiles exist in relatively low areas such as the MENA region (the Middle East and North Africa), where water is scarce. 
The comparative advantage notion takes on major political significance related to strategic commodities such as food and energy. The concept of virtual water is something of a descendant of the idea of comparative advantage. Virtual water happens to be integral to the strategic commodity of food. Simultaneously, it cannot escape a contentious role in the discourse on food security's political economy. Virtual Water's potential part is so controversial that managing water and developing water policy in water-scarce economies ensure that the concept is kept out of Water policymaking discourse (Allan, 2001a).

\section{7- Virtual Water:}

Tony Allan introduced 'virtual water' in the early 1990s (Allan, 1993). It took almost a decade to gain global awareness of the concept's significance to achieving regional and global water protection. The first international meeting on the subject was held in Delft, The Netherlands, in December 2002. A special session at the Third World Water Forum in Japan, March 2003, is also devoted to virtual water.

'Virtual water' is a newly emerging strategy idea, developed as a long-term perspective approach to increase the stress on water supplies worldwide. It implies that water-poor countries import agricultural products that need large quantities of water to be produced from other areas that are more water-endowed. 
Therefore, virtual water is a useful metaphor, which sheds light on the water efficiency gains associated with regional and international trade. However, to enhance its policy relevance, it is vital to refine the current analysis by considering water consumption in its direct and indirect components and distinguishing the different water sources and their opportunity costs. Virtual water was also linked to water footprint, which is "the volume of water required to produce the goods and services consumed by a country 's inhabitants" (Chapagain and Hoekstra, 2003).

\section{8- Virtual Water Definitions:}

This section includes important definitions related to virtual water (D'Odorico et al., 2019):

- Virtual water content (VWC): is the amount of water required to create a good, taking into account all the steps involved in its creation. The word virtual underlines that water is conceptually embedded but not physically present in the good. In this way, the name material may be misleading, although widely used and in contradiction with the term virtual, since virtual water is not actually in the commodity. The VWC is typically expressed as the water volume per unit product mass (in $\mathrm{m}^{3}$ ton $^{-1} \mathrm{or} \mathrm{kg}^{-1}$ ). For example, the actual average water content of wheat in the United States of America is about $0.13 \mathrm{~m}^{3}$ ton $^{-1}$, while the VWC is about $1961 \mathrm{~m}^{3}$ ton $^{-1}$. 
- Crop water footprint (CWF): is the same as VWC but applies explicitly to crops. CWF is measured as the ratio of total crop evapotranspiration in growing season and crop yield and is expressed as a volume of water per unit product mass (in $\mathrm{m}^{3}$ $\operatorname{ton}^{-1}$ or $\mathrm{kg}^{-1}$ ). The footprint can be determined using productionbased accounting (PBA) or, most commonly, through Consumer Accounts (CBA). PBA refers to production-related impacts and resource inputs. CBA locates those manufactured goods to end consumers. However, in the case of crops, the bulk of the water footprint is contributed during the production cycle by water loss by evapotranspiration. The cost of storing and transporting water is negligible. Therefore, conceptual distinguishing between PBA and $\mathrm{CBA}$ is unnecessary, and the water costs of crop production will be expressed simply in terms of CWF.

-Water footprint (WF): describes the amount of water associated with a certain mass of goods and a collection of goods (not unit). Computing can take various approaches.

The green water footprint is a fraction of the WF added by green water ( i.e., precipitation water adding directly to the soil water balance in the crops' root zone in the absence of irrigation).

Bluewater footprint: The WF fraction contributes to the use of blue water ( i.e., irrigation water diverted from surface water sources and aquifers). 
A Gray water footprint is a freshwater pollution indicator defined as the water volume needed to dilute contaminants to a concentration that meets the water quality standards.

- Virtual Water Trade (VWT): is the (international or intranational) trade-in virtual water-related products. By trade in derivatives, water supplies, which are physically used in production, are essentially transferred to the area of consumption. This transfer creates a virtual flux of water, which connects the output to consumption.

\section{9- Virtual Water Trade and Water Footprint Calculations:}

\section{1- Virtual water-trade calculation:}

The virtual water trade for a single crop c, from a given location ( e.g., country) I to another location j, $\mathrm{VWT}_{\mathrm{c}}$, ij $\left(\mathrm{m}^{3} \mathrm{yr}^{-1}\right)$ depends on both the virtual water footprint of the crops from that location, $\mathrm{VWF}_{\mathrm{c}, \mathrm{I}}\left(\mathrm{m}^{3} \operatorname{ton}^{-1}\right)$ and the commercial sum of that crop $\mathrm{T}_{\mathrm{c}, \mathrm{ij}}\left(\right.$ ton $\mathrm{yr}^{-1}$ ) or,

$\mathrm{VWT}_{\mathrm{c}, \mathrm{ij}}=\mathrm{VWC}_{\mathrm{c}, \mathrm{i}} \mathrm{T}_{\mathrm{c}, \mathrm{ij}}$

Thus, to understand global patterns of virtual water trade, the resolution of a crop's virtual water content from a given location and trade volume is needed. The use of water from a particular crop, both green (rain) and blue (water withdrawals from ground or surface water), is essential to restrict the virtual material, or 
water footprint, of that crop for a specific location and growing season (D’Odorico et al., 2019).

\section{2- The Water Footprint calculation:}

The water footprint is the amount of water needed to generate a product or asset of resources (produced or consumed). When combined with the intake of water (i.e., the water returned during the manufacturing cycle as water vapor to the atmosphere), this may include both rainwater (green water) and surface water (blue water) or groundwater. For example, crop production consumes both green water and blue water for irrigated farming. Evapotranspiration triggers these consuming uses of water by crops. Research on water footprint have employed different approaches:

1) The biophysical method, which is used mainly for crops and agricultural products, calculates $\mathrm{CWF}$ as the ratio between evapotranspiration and crop yield. The CWF is then multiplied by the mass of product traded to approximate VWT, and the resulting amount of water is then summed up over the different products. In general, VWT is measured using the country of origin CWF of the trade flow. Such an approach is generally referred to as the bottom-up approach (Feng et al., 2012).

2) Life Cycle Analysis (LCA) approaches use LCA datasets that include a product library called water footprint. The LCA 
strategy involves multi-stage supply chains, thus attributing cotton water use to a non-textile manufacturer country's final purchaser of a t-shirt and correcting for re-export (e.g., Dutch forwarding of products to Germany).

3) Top-down methods refer to input-output analyses commonly used in economics to examine the usage and distribution of water in countries or areas. Top-down approaches calculate the WF using a Leontief demand-pull model to trace water usage in regional, national, or global supply chains. In particular, multiregional input-output (MRIO) analyzes global supply chains' use and allows estimation of national totals ( Yang et al., 2012) (Arto et al., 2016). Nevertheless, the product resolution is often small, as emphasized in Feng et al. (2012). For example, all agricultural products are usually known as bulk goods or categorized into a few categories. Recent advances in water footprint analysis on the MRIO are geared towards enhancing product resolution (Lutter et al., 2016).

4) Finally, the implementation of hybrid methods using both a monetary MRIO for monitoring embodied products and a physical model (e.g., based on FAO STAT) could find a reasonable balance between top-down and bottom-up approaches to track physical flows (Bruckner et al., 2015), (de Koning et al., 2015), (Giljum et al., 2015). 


\section{0- Virtual Water Trade as an Analytical Instrument and a Political Strategy:}

The idea of virtual water by Tony Allan was initially intended to facilitate a peaceful exchange of water in water-intensive resources for countries with water deficits. Nevertheless, as Sandra Postel and others point out, some conditions remain in today's dynamic international political economy for useful virtual water trade that would lead to peace. It will lead to even more contradictory situations in the rapidly evolving global trading environment unless a collection of standards, values, laws, and decision-making processes are carefully developed and virtually converged upon (Islam, M.S., 2007).

Unlike real water exchange, a productive virtual water-trading network in a similar culture will act as a virtual currency, sharing the norms and principles of integrated water resource management and governance.

Theoretically, the virtual water strategy is a robust solution for water resource problems. Since the main advantage of the virtual water strategy is its redistributive effect on the global level in the form of the international trade of goods and services, this requires a fair and reliable system of international trade.

As an empirical term, the theory of virtual water has been a groundbreaking advance in recognizing the global 
interrelationships of water resources, rating the present probable viewpoint of water scarcity as a catastrophe. It is not oblivious to its political consequences either, maintaining that the system will remain invisible to prevent social tension for its remarkable financial advantages predicated (Allan, 2001).

Virtual water is economically invisible and politically silent has the incredible advantage of allowing water policymakers and managers to cultivate a policy discourse in which it can be assumed that there is no national water or food deficit (El-Gafy, I. K., 2014).

Further work along the same lines enabled useful insights for the Middle East and North Africa economies. The less than satisfactory results were mainly because only Freshwater was taken into account; soil water estimates were not available. The inclusion of soil water will improve the predictive results of the Hecksher-Ohlin model. But the initial negative experience of deploying the theory seemed to confirm that it was the power of the virtual water concept to draw attention to the ameliorating process of the virtual water trade that was its principal value. Rather than its capacity to predict exact volumes transacted. Within a couple of days of receiving the 2002 Hoekstra and Hung report in Delft, the author was in Sri Lanka, a relatively water-rich country (Mekonnen, M.M., Hoekstra, A. Y., 2012). 
The island does, however, endure periods when the monsoon rains are seriously below average. A severe deviation from the rainfall norms occurred in 1996, 1997, and 1998. As a result, Sri Lanka's food imports rose dramatically (Hoekstra and Hung, 2002). The levels of imports were such that for the five years, 1995 to 1999, Sri Lanka topped the global list of virtual water importers, even outranking Japan by 44 percent. Yet, in standard years, Sri Lanka imports scarce food (Hoekstra and Hung, 2002). The Sri Lankan case is critical in highlighting the immense flexibility of the virtual water solution. In addition to its three significant virtues of being first very useful in addressing water deficits, it is secondly economically invisible, and thirdly, politically silent.

Virtual water has the fourth essential virtue. Water found in food products can be mobilized rapidly and flexibly to meet the everchanging demands of those chronic water shortages and staple food. This flexibility to remedy periodic water shortages outmatches any security measures deployed by engineers to store water behind dams. The hydraulic actions have local impacts. The virtual water remedy is global in its reach. The virtual water remedy is also immensely more potent than any policies deployed to manage demand. Water use can end contained in industrialized economies located in arid and semi-arid regions, but slowly. Water use in irrigated agriculture was reduced by about 20 percent in California after 1980 and 30 percent in Israel 
from 1986 to 1991 . However, no hydraulic system can stream the volumes of water needed to mobilize staple foods, as can the virtual water system (Allan, 2003).

\section{1- Water Savings from Virtual Water Trade:}

Foreign trade can save national water supplies by importing waterintensive goods from outside the world. Through trade, nationwide water savings will lead to global water savings if the flow is from high sites to low water productivity sites (Chapagain et al., 2006), (Martinez-Melendez and Bennett, 2016), (Brindha, 2017 ).

It has been reported that VWT is saving $352 \mathrm{~km}^{3} \mathrm{yr}^{-1}$, which would otherwise be used in the importing countries to manufacture agricultural products (Chapagain et al., 2006). Other studies found lower savings and recorded an increasing increase, from approximately $50 \mathrm{~km}^{3} \mathrm{yr}^{-1}$ in 1986 to $240 \mathrm{~km}^{3} \mathrm{yr}^{-1}$ in 2008 (Dalin et al., 2012a).

Water-scarce nations and regions conserve water supplies on average through the purchase of food commodities. VWT, for example, is estimated to ease water tension and foster water quality in China (Zhao et al., 2018). VWT alleviates water scarcity when entering wealthy countries, although it has minimal water scarcity effects in poorer countries (Distefano and Kelly, 2017). 
In some instances, foreign trade can also increase agricultural commodity production's water consumption if crops are grown in less environmentally productive and more wasteful ways (Martinez-Melendez and Bennett, 2016).

Many countries generate food at the risk of more pressure on their water supplies. For example, they are often traded from an area with low water productivity to a region with higher water savings from processing (Lamastra et al., 2017).

However, regional trade in Africa is much more effective regarding embodied water supplies than any other region in the world. So internal African trading patterns in their domestic production systems can compensate for low water productivity (Konar and Caylor, 2013).

Konar et al. ( 2013) have shown that the amount of water savings is likely to grow under a changing environment. Even though under climate change, the total amount of VWT is expected to grow due to higher crop prices. Power savings occur under climate change as crop exchange reorganizes into a more powerefficient system (Konar et al., 2013).

The amount of global water savings increases even more when free trade policies are allowed under a changing environment (Konar et al., 2016b). This suggests that trade liberalization leads to more effective water supplies in the global trading system, 
making it a potentially important measure for adapting to climate change (Konar et al., 2016b).

These results are backed by recent causal inference work that shows that openness to trade leads nations to use, on average less of their domestic water supplies (Dang and Konar, 2018).

\section{2- Advantages and Disadvantages of Virtual water trade in Egypt:}

The policy options offered by the Virtual Water trade definition and the suitability of such an opportunity for Egypt should be investigated. For most developed, emerging, and least developed countries, the concept of virtual water is essential. Local planning and regional cooperation incorporating the notion of virtual water trade could result in the exchange of goods, the diversification of crops for any country, diet awareness formation, or crop replacement acts.

On the other hand, scholars in Egypt more often than not contradict Tony Allan's political claim from the beginning of the virtual water debate that virtual trade in water can be an instrument to solve geopolitical problems and even prevent wars over Water (Allan, 1998) (Allan, 2003).

The inconsistency is based on the belief that most western countries are food-exporting nations and the relationship between Skepticism and the fear of conquest rule Egypt and Western 
countries. Thus, it is viewed by Egypt, looking at the big picture, that reliance on food imports would lead to foreign dominance. Next to the political scale, the economic dimension exists, stressed equally by Allan $(1997,1999,2001)$.

According to the international trade theory, the economic argument behind virtual water trade is that nations should export products with a relative or comparative production advantage while importing products with a comparative disadvantage (Wichelns, 2001).

Furthermore, growing food (i.e., feeding oneself) has other essential aspects besides economic or political ones; cultural and social factors have a significant effect on the decision whether to grow a specific crop or not. Hoekstra and Hung (2005) and Hoekstra and Chapagain (2007) argue that while pricing and technology can be a means of increasing the efficiency of local water use and reallocating water to its higher value at the basin scale, virtual water trade between nations can be a tool to increase the efficiency of global water use.

From an economic point of view, in those places where water is most abundantly available, it makes sense to manufacture the water-intensive products needed in this world. Water is cheaper in these areas, there are smaller negative externalities to water use, and less water is also required per product unit. Virtual trade in water from a country where water productivity is relatively 
high to a country where water productivity is relatively low means real water savings are made globally.

As stated before, previous food security policies have been focused on the expansion of the region to support food selfsufficiency goals and increase exports. These expansions have proven unsustainable concerning the water supplies available and have contributed to real challenges to the sustainability of existing developments.

Indeed, the increased productivity of land and water, both in terms of higher yields and cropping intensities for which scope still exists, would lead to potential increases in agricultural production. This would contribute to higher water savings by reducing wastewater to low-value crops and achieving more effective water use and improved agricultural practices. Egypt needs to be assured that it can have equal and safe trade with water-abundant nations before implementing the virtual water policy alternative (Hoekstra, \& Chapagain, 2007).

In short, the principle of virtual water is well known, given that countries have a more transparent image of their comparative advantage and can thus convert it into a competitive advantage. The second issue relates to the extent of the economic base, i.e., whether the country's economy is well developed and diversified to determine whether to reallocate cereal water, which provides 
subsistence living conditions for large sections of the rural population ( Hoekstra, \& Hung, 2005).

Regional cooperation in this field is vital as it would allow countries in the region to evaluate and examine the situation more generally, taking into account common strategic issues. Other costs to be considered, in addition to direct financial costs, related to imports by countries with a water deficit to resolve food shortages are (WWC, 2004): (1) increased reliance on the significant exporting countries; (2) local agriculture may be harmed by importing food if it is unable to compete or adapt; (3) the exporting country may begin to interfere with the internal affairs of the importing country; and (4) imports may lead to the depletion of foreign reserves if there is no export compensation for commodities which are less water-intensive or of higher value.

\section{Conclusion:}

Understanding the definition and strategy of virtual water trade is critical for formulating informed policies to improve water usage efficiency at various levels. In Egypt, the implementation of the meaning of virtual water as a water-saving technique is still in need of comprehensive study, research, and feasibility evaluation. Nowadays, among those water-poor nations, Egypt is counted. This condition is mainly due to its dwindling freshwater supply and the steady rise in water demand. Consequently, Egypt 
is increasingly relying on innovative technology and appropriate policies that promote integrated water resources management.

For a country like Egypt, affordability is not that of implementing virtual water but rather that of priority and freedom relating to food security. There is a need to have a clear vision and understanding of its advantages and drawbacks under Egyptian conditions to implement the virtual water definition in Egypt's national water management strategy.

These aspects need to be subject to a systematic review and study of science. While imports of virtual water trade will relieve the pressure on national water resources, further research and understanding of the impacts on the local social, economic, environmental, cultural, natural, and political situation are needed to include this new concept as a policy option for Egypt. 
Virtual Water Trade as a creative water-saving technique

Hadeer Khaled Mohamed El-Sayed El-Batanouny

\section{References:}

Abdel-Shafy, H. I., \& Aly, R. O. (2002). Water issue in Egypt: Resources, pollution and protection endeavors. Central European Journal of Occupational and Environmental Medicine, 8(1), 3-21.

Abu Zeid, M. (2007). Water Resources assessment for Egypt .International Journal Water Resources. Dev. 8 (2), 76-86.

Ahmed, M., 2002. Water Pricing and Markets in Near East, policy issues and options. Water policy. 2: pp.229-242

Allan, J. A. (1993), Fortunately, there are substitutes for water otherwise our political futures would be impossible. ODA Priorities for Water Allocation and Management. (London:ODA)

Allan, J. A. (1998), Virtual Water: a strategic resource.Ground Water 36, 545-7.

Allan, J. A. (2003), Virtual water -the water, food, and trade nexus. Useful concept or misleading metaphor?. Water Int., 28 106-13.

Allan, J. A. (1998), Virtual Water: a strategic resource. Global solutions to regional deficits. Groundwater 36(4):545-546.

Allan, J. A. (1999), Water stress and global mitigation: water food and trade. Arid Lands Newsletter.

Allan, J. A. (2001), The Middle East water question: hydropolitics and the global economy. Tauris, London.

Allan, T. (1997), Virtual Water: a long term solution for water short Middle Eastern economies?. British Association Festival of Science, Roger Stevens Lecture Theatre, University of Leeds, Water and Development Session-TUE 51:14.45. 
Virtual Water Trade as a creative water-saving technique

Hadeer Khaled Mohamed El-Sayed El-Batanouny

Amarasinghe, U. A., Mutuwatta, L. \& Sakthivadivel, R. (1999), Water Scarcity variations within a country, A case study of Sri-lanka, Research report 32, Colombo, Sri-Lanka, International Water Management Institute, 1-30.

Arto, I., Andreoni, V., \& Rueda- Cantuche, J. (2016), Global use of water resources: A multi-regional analysis of water use, water footprint and water trade balance. Water Resour. Econ. ,151-14.

Bates, P. D., Dawson, R. J., Hall, J. W., Horritt, M. S., Nicholls, R. J., Wicks, J., \& Hassan, M. A. A. M. (2005). Simplified twodimensional numerical modelling of coastal flooding and example applications. Coastal Engineering, 52(9), 793-810.

Brindha, K. (2017), International virtual Water flows from agricultural and livestock products of India. 161922-30

Bruckner, M., Fischer, G., Tramberend, S., \& Giljum, S. (2015), Measuring telecouplings in the global land system: a review and comparative evaluation of land footprint accounting methods. Ecol. Econ.11411-21.

CAPMAS (2017), Egypt in Figures, Egypt.

Chapagain, A. K., Hoekstra, A. Y., \& Savenije, H. H. G. (2006), Watersaving through international trade of agricultural products Hydrol. EarthSyst. Sci. Discuss. 10455-68.

Chapagain, A. K.,\& Hoekstra, A.Y. (2003), Virtual Water flows between nations in relation to trade in livestock and livestock products. Value of Water Research Report Series no. 13. UNESCO-IHE, Delft, the Netherlands. 
Virtual Water Trade as a creative water-saving technique

Hadeer Khaled Mohamed El-Sayed El-Batanouny

Dalin, C. et al. (2012a), Evolution of the global virtual water trade network. Proc. Natl Acad.Sci.1095989-94.

Dang, Q., \& Konar, M. (2018), Trade openness and domestic water use. Water Resour. Res. 54 4-18

De Koning, A., Bruckner, M., Lutter, S., Wood, R., Stadler, K., \& Tukker, A. (2015), Effect of aggregation and disaggregation on embodied material use of products in input-output analysis. Ecol. Econ. 116289-99.

Distefano, T., \& Kelly, S. (2017), Are we in deep water? Water scarcity and its limits to economic growth. Ecol. Econ. 142130-47.

D'Odorico et al. (2019), Global virtual water trade and the hydrological cycle: patterns, drivers, and socio-environmental impacts, Environ. Res. Lett. 14(053001), 1-33.

El-Gafy, I. K. (2014), System dynamic model for crop production, water footprint, and virtual water nexus, Water Resources Management, 28 (13), 4467-4490.

El-Sadek, A., El Kahloun, M., \& Meire, P. (2008), Ecohydrology for integrated water resources management in the Nile basin. Ecohydrol Hydrobiol 8(2-4):237-244

ENCID, (1996), Egyptian National Committee on Irrigation and Drainage (1996), Egypt. www.icid.orglv_egypt.pdf

FAO, (2017a), Aquastat [WWW Document]. Food Agri. Organ., Rome. URL. http://www.fao.org/nr/water/aquastat/data/query/index.html?long=en. (Accessed 29 September 2017) 
Virtual Water Trade as a creative water-saving technique

Hadeer Khaled Mohamed El-Sayed El-Batanouny

Feng, K., Siu, Y. L., Guan, D., \& Hubacek, K. (2012), Assessing regional virtual water flows and water footprints in the Yellow River Basin, China: a consumption based approach. Appl. Geogr. 32, 691-701.

Giljum, S., Bruckner, M., \& Martinez, A. (2015), Material footprint assessment in a global input- output framework. J.Ind.Ecol.19, 792-804.

Hadddadin, M. (2003), water in the Middle East peace process, The Geographical Journal, V1. 168, 324-340.

Hoekstra, A. Y., \& Hung, P. Q. (2002), Virtual water trade: a quantification of virtual water flows between nation in relation to international crop trade Value of Water. Research Report Series No.1.

Hoekstra, A. Y., \& Chapagain, A. K. (2007), Water footprints of nations: water use by people as a function of their consumption pattern. Water Resour Manag 21(1):35-48.

Hoekstra, A. Y., \& Hung, P. Q. (2005), Globalization of water resources. Global Environ Change 15:45-56

ICID, (2005), Water Policy Issues of Egypt. Country Policy Support Programme (CPSP) Project funded by The Govt. of The Netherlands.

Islam, M. S., Oki, T., Kanae, S., Hanasaki, N., Agata, Y., \& Yoshimura, K. (2007), A grid-based assessment of global water scarcity including virtual water trading. Water Resour Manag 21(1):19-33.

Konar, M., Hussein, Z., Hanasaki, N., Mauzerall, D. L., \& RodriguezIturbe, I. (2013), Virtual water trade flows and savings under climate change. Hydrol. Earth Syst. Sci. 173219-34. 
Virtual Water Trade as a creative water-saving technique

Hadeer Khaled Mohamed El-Sayed El-Batanouny

Konar, M., Reimer, J. J., Hussein, Z., \& Hanasaki, N. (2016b), The water foot print of staple crop trade under climate change and policy scenarios. Environ. Res. Lett. 11035006.

Konar, M., \& Caylor, K. (2013), Virtual water trade and development in Africa ,Hydrol. Earth Syst. Sci. 173969-82

Lamastra, L., Miglietta, P. P., Toma, P., De Leo, F., \& Massari, S. (2017), Virtual water trade of agri-food products : evidence from italianchinese relations. Sci.Total Environ. 599474-82

Lutter, S. et al. (2016), Spatially explicit assessment of water embodied in European trade: a product- level multi-regional input-output analysis. Glob.Environ. Change 38, 171-82.

Martinez-Melendez, L. A., \& Bennett, E. M. (2016), Trade in the US and Mexico helps reduce environmental costs of agriculture. Environ. Res.Lett. 11055004.

Mekonnen, M. M., \& Hoekstra, A. Y. (2012), A global assessment of the water footprint of farm animal products, Ecosystems 15 (3), 401415 .

Mohamed, Y. A., \& Loulseged, M. (2008), The Nile basin water resources: overview of key research questions pertinent to the Nile basin intiative, Colombo, Sri-Lanka, International Water Management Institute, 1- 34 (IWMI, Working paper127).

Molden, D., Frenken, K., Barker, R., Fraiture, C., de Mati, B., Svendsen, M., Sadoff, C., Finlayson C.M., Attapatu S. (collab.), Giordano M. (collab.), Inocencio A. (collab.), Lannerstad M. (collab.), Manning N. (collab.), Molle François (collab.), Smedema B. (collab.), Vallée D. (collab.) (2007). Trends in water and agricultural development. In 
Virtual Water Trade as a creative water-saving technique

Hadeer Khaled Mohamed El-Sayed El-Batanouny

: Molden D. (ed.) Water for food, water for life : a comprehensive assessment of water management in agriculture. Londres : Earthscan, 57-89. ISBN 978-1-84407-396-2

MWRI, (2002), Adopted measures to trace major challenges in the Egyptian water sector, A report submitted at the request of world water council for 3 rd world water forum. Cairo, Egypt.

MWRI, (2005), National Water Resources Plan for Egypt 2017, Cairo, Egypt.

MWRI, (2010), Strategy of Water Resources of Egypt till 2050, Ministry of Water Resources and Irrigation.

UNEP, (2003), Global Marine Assessments a survey of global and regional marine environmental assessments and related scientific activities, UNEP, UNESCO, Book, IOC, 132.

United Nations Environment Programme (UNEP), (2002), Vital Water Graphics. An Overview of the State of the World's Fresh and Marine Waters. New York, NY: United Nations Environment Programme.water trade. UNESCO-IHE Inst. for Water Educ., Delft, Netherlands, 137-145.

Wichelns, D. (2001), The role of virtual water in efforts to achieve food security and other national goals, with an example from Egypt. Agric Water Manag 49:131-151.

Wichelns, D. (2001), The role of virtual water in efforts to achieve food security and other national goals, with an example from Egypt. Agricultural Water Management 49: 131-151. 
Virtual Water Trade as a creative water-saving technique

Hadeer Khaled Mohamed El-Sayed El-Batanouny

Yang, Z., Mao, X., Zhao, X., \& Chen, B. (2012), Ecological network analysis on global virtual water trade. Environ. Sci. Technol. 46, 1796-803.

Zhao, X. ,Li, Y. P., Yang, H., Liu, W.F., Tillotson, M. R. ,Guan, D. ,Yi, Y., \& Wang, H. (2018), Measuring scarce water saving from interregional virtual water flows in China Environ. Res. Lett. 13054012

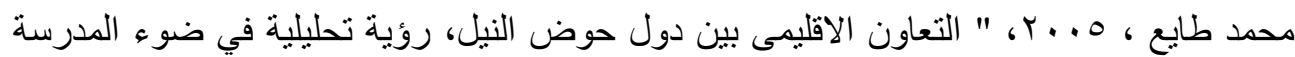

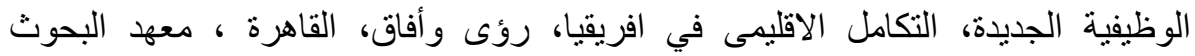
و الدارسات الافريقية بجامعة القاهرة. 